\section{Single dose omeprazole on plasma bupivacaine concentrations following epidural administration}

\section{To the Editor:}

The observation that omeprazole is metabolised by the hepatic cytochrome P-450 enzyme system, mainly by CYP2C but involving several different $\mathrm{P}-450$ isoenzymes, and that omeprazole inhibits P-450 mediated metabolism, raises the possibility of potential interactions between it and other drugs metabolised by this system. ${ }^{1-2}$ While the P-450 system demonstrates remarkable isoenzyme specificity, there is considerable overlap of substrate specificity. ${ }^{3}$ We investigated the interaction profile of omeprazole with the local anaesthetic bupivacaine, which is metabolised by cytochrome P- 450 enzymes and which is often used concurrently with omeprazole in anaesthetic practice. ${ }^{4}$

Twenty adult, matched patients, 10 per group, were randomised to receive no medication or $40 \mathrm{mg}$ omeprazole po, two hours before epidural bupivacaine $(80 \mathrm{mg})$. Venous blood samples were taken for bupivacaine assay, before and at 15, 30, 45, 60 and $120 \mathrm{~min}$ after bupivacaine administration. The samples were centrifuged and the supernatant plasma stored at $-20^{\circ} \mathrm{C}$ until assayed by gas chromatography mass spectrometry using $2 \mathrm{H} 3$-bupivacaine as the internal standard. There was no difference between the control and omeprazole group in the area under the plasma concentration against time curve at 120 $\min \left(170 \pm 24.1 ; 185 \pm 12.3 \mathrm{~mol} \cdot \mathrm{min}^{-1} \cdot \mathrm{L}^{-1}\right) ;$ maximum plasma bupivacaine concentration $(1.97 \pm 0.4 ; 1.67 \pm 0.2$ mol. $\left.\mathrm{L}^{-1}\right)$ or time of its occurrence $(0.25 \pm 0.02 ; 0.25 \pm$ 0.0 hours). Bupivacaine concentrations decreased after Cmax with a similar trend in both groups (Figure).

There is no suggestion that single dose omeprazole administered orally interferes with plasma bupivacaine levels. It is therefore a safe single dose antacid therapy before regional anaesthesia with bupivacaine.

Dowd N.P. MB FFARCSI

Taylor A. MB FFARCSI

Moriarty D.C. FRCA FFARCSI

Blunnie W.P. FFARCSI

Mater Misericordiae Hospital

Dublin, Ireland

\section{REFERENCES}

1 Tucker GT. The interaction of proton pump inhibitors with cytochrome P450. Alimentary Pharmacol Ther 1994; 8(Suppl 1): 33-8.

2 Noble DW, Bannister J, Lamonte M, Andersson T, Scott $D B$. The effect of oral omeprazole on the disposition of lignocaine. Anaesthesia 1994; 49: 497-500.

3 Hansten PD. Drug interactions with antisecretory agents. Alimentary Pharmacol Ther 1991; 5(Suppl 1): 121-8.

4 Piblajamaki K, Kanto J, Lindberg $R$, Karanko M, Kiilholma $P$. Extradural administration of bupivacaine: pharmacokinetics and metabolism in pregnant and non-pregnant women. Br J Anaesth 1990; 64: 556-62.

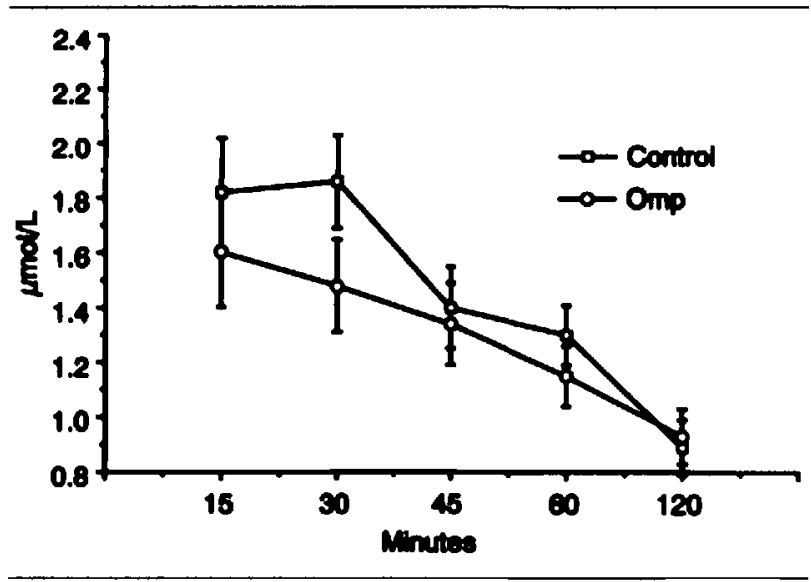

FIGURE Mean (SEM) plasma bupivacaine concentrations in the control and omeprazole groups. Bupivacaine levels were lower, but not significantly) in the omeprazole group than in the control all time points except at $120 \mathrm{~min}$. 